\title{
ОСОБЛИВОСТІ ГАЗОРОЗРЯДНОГО СВІТІННЯ ПАЛЬЦІВ РУК ЛЮДИНИ ПРИ РІЗНИХ ТИПАХ ЕНЕРГЕТИЧНОЇ АКТИВНОСТІ
}

\author{
Л. А. Пісоцька, Н. В. Глухова ${ }^{1}$, Т. О. Третяк², \\ О. В. Пісаревська, М. Г. Гетман, Т. А. Симонова \\ ДЗ «Дніпропетровська медична академія МОз України» \\ ${ }^{1}$ Національний гірничий університет \\ ${ }^{2}$ Дніпровський національний університет імені Олеся Гончара
}

\begin{abstract}
Обстежено 52 практично здорових студенти. 3 них 28 осіб були молодших курсів навчання та $24-$ студенти старших курсів. За результатами психологічних тестів визначали три типи мислення: наочно-образне, словеснологічне, інтуїтивне. Проводили кірліан-фотографування пальців рук обстежуваних осіб на експериментальному приладі «РЕК 1». Методи реєстрації, обробки та подальшого аналізу включали аналого-цифрове перетворення кірліанівських зображень з метою виділення областей світіння окремих пальців, бінаризацію зображень за порогом яскравості світіння, обчислення площі корони світіння. Отримані результати доповнили результати психологічних тестів, виявили змішані типи мислення, їх виразність, залежність від терміну навчання в університеті. Для виявлення психоемоційних особливостей студентів, пов'язаних із конституційним типом особистості, проводили вибірково кірліанографічне дослідження на кольоровій фротоплівці «Поляроїд» із комп'ютерним обробленням відсканованих зображень. Реєстрація на кольоровій фотоплівці випромінювання навколо пальців рук обстежених осіб, визначення співвідношень кольорів зображення, їх енергетики дозволили визначити тип психоемоційної активації організму та потенційні власні здібності студента, що вливають на мотивацію й оптимізацію навчання в університеті.
\end{abstract}

Ключові слова: кірліанографрія, студенти, мислення, Ро-, кольорова фротоплівка, комп'ютерне оброблення інфрормації.

\section{FEATURES OF HUMAN FINGERS GAS-DISCHARGE GLOWING IN DIFFERENT TYPES OF ENERGY ACTIVITY}

\author{
L. A. Pesotskaia, N. V. Hlukhova ${ }^{1}$, T. O. Tretiak', \\ O. V. Pysarevskaia, M. H. Hetman, T. A. Symonova \\ SE «Dnipropetrovsk medical academy of Health Ministry of Ukraine» \\ ${ }^{1}$ National Mining University \\ ${ }^{2}$ Oles Honchar Dnipro National University
}

\begin{abstract}
There were 52 healthy people. Of them, 28 were in junior courses and 24 were in senior courses. According to the results of psychological tests there were identified three types of thinking: visual-figurative and verbal-logical, intuitive. Kirlian photographs of the surveyed individuals fingers in the experimental device «REC 1» were done. The method of acquiring, processing, and subsequent analysis included analog-to-digital conversion Kirlian images to highlight areas of illumination of the individual fingers, binarization of images with the threshold brightness, calculation of the area of corona glow. The obtained results complemented results of psychological tests, revealed mixed types of thinking, their expression, the dependence of the period of study at the university. To identify the emotional characteristics of the students associated with the constitutional type of the individual, selectively kronograf research on Polarod color photographic film with computer processing of scanned images carried out. Check radiation around the fingers of people surveyed in the color film, determination of the ratios of colors in the image, their energy allowed to determine the type of emotional activation of student body's potential abilities that affects motivation and optimize learning at the university.
\end{abstract}

Key words: kronograf, students, thinking, Ro-, color photographic film, computer processing of information. 


\title{
ОСОБЕННОСТИ ГАЗОРАЗРЯДНОГО СВЕЧЕНИЯ ПАЛЬЦЕВ РУК ЧЕЛОВЕКА ПРИ РАЗНЫХ ТИПАХ ЭНЕРГЕТИЧЕСКОЙ АКТИВНОСТИ
}

\author{
Л. А. Песоцкая, Н. В. Глухова ${ }^{1}$, Т. О. Третяк², \\ О. В. Писаревская, М. Г. Гетман, Т. А. Симонова \\ ГУ «Днепропетровская медицинская академия МЗ Украины» \\ ${ }^{1}$ Национальный горный университет \\ ${ }^{2}$ Днепровский национальный университет имени Олеся Гончара
}

\begin{abstract}
Обследовано 52 практически здоровых студента. Из них 28 человек обучались на младших курсах и $24-$ студенты старших курсов. По результатам психологических тестов определяли три типа мышления: наглядно-образное, словесно-логическое, интуитивное. Проводили кирлиан-фотографрирование пальцев рук обследуемых на экспериментальном приборе «РЕК 1». Методы регистрации, обработки и последующего анализа включали аналого-цисровое преобразование кирлиановских изображений с целью выделения областей свечения отдельных пальцев, бинаризацию изображений за порогом яркости свечения, вычисление площади короны свечения. Полученные результаты дополнили результаты психологических тестов, выявили смешанные типы мышления, их выраженность, зависимость от срока обучения в университете. Для выявления психоэмоциональных особенностей студентов, связанных с конституционным типом личности, проводили выборочно кирлианограсрическое исследование на цветной фотопленке «Поляроид» с компьютерной обработкой отсканированных изображений. Регистрация на цветной фротопленке излучения вокруг пальцев рук обследованных, определение соотношений цветов изображения, их энергетики позволило определить тип психоэмоциональной активации организма и собственные потенциальные способности студента, что влияет на мотивацию и оптимизацию обучения в университете.
\end{abstract}

Ключевые слова: кирлианография, студенты, мышление, Ро-, цветная фотопленка, компьютерная обработка инорормации.

Вступ. Зображення газоразрядного світіння (ГРС) пальців людини містять ряд інформаційних ознак, що корелюють з ії психологічним станом [3]. Вiдомі можливості кірліанографіі пальців рук на кольоровому фотоматеріалі для оцінювання психоемоційної активності та природних здібностей людини $[4,6]$. Актуальною є розроблення інструменту комп’ютерного оброблення зображень ГРС пальців рук для прикладного застосування в психологічній науці, зокрема, для встановлення ознак різного типу розумового процесу у студентів.

Мета дослідження: розроблення програмноприкладного методу для встановлення особливостей ГРС пальців рук у студентів при різних типах мислення за результатами психологічних тестів.

Матеріали та методи дослідження. В обстеженні та тестуванні взяли участь 52 практично здорових студенти. Обстежили 28 осіб молодших курсів навчання та 24 - старших курсів. За результатами психологічних тестів визначали три типи мислення: наочно-образне, словесно-логічне, інтуїтивне.

Кірліан-фотографування пальців рук обстежуваних осіб проводили на експериментальному приладі «РЕК 1», розробленому Українським науково-дослідним інститутом технологій машинобудування (м. Дніпро) [1]. Для кожного 3 учасників було отримано чотири кірліан-фотографії: контроль і після проведення кожного психологічного тесту з 15-хвилинним інтервалом. Проводили комп'ютерний аналіз зображень ГРС навколо 3-го та 4-го пальців правої руки, що відповідають за схемами П. Мандела [5] реактивним регулюючим системам організму (серцево-судинна, ендокринна, психіка).

Метод реєстрації, обробки та подальшого аналізу параметрів зображень газоразрядного випромінювання викладено раніше [2]. Він включав аналогоцифрове перетворення кірліанівських зображень 3 метою виділення областей світіння окремих пальців, бінаризацію зображень за порогом яскравості світіння, обчислення площі корони світіння (ПКС).

Обирали тип мислення з максимальною площею засвічення Smax, що порівнювали з площами світіння при інших типах мислення на 3-му та 4-му пальцях окремо. За ступенем різниці між ними визначали рівень прояву того чи іншого типу мислення.

Для виявлення пов'язаних із конституційним типом особистості психоемоційних особливостей студентів проводили вибірково кірліанографічне дослідження на кольоровій фотоплівці «Поляроїд» 3 комп’ютерною обробкою відсканованих фотоплівок.

Результати та їх обговорення. За отриманими результатами виділили такі групи студентів: із одним переважаючим з перерахованих вище типом мислення та змішаний тип при близьких величинах 
Результати високих ПКС (20 тис. у. од. і більше) у студентів за типом мислення

\begin{tabular}{|l|c|c|c|c|}
\hline \multirow{2}{*}{ Тип мислення } & \multicolumn{2}{|c|}{ 3-й палець } & \multicolumn{2}{c|}{ 4-й палець } \\
\cline { 2 - 5 } & $\begin{array}{c}\text { Молодші курси, } \\
\mathrm{n}(\%)\end{array}$ & $\begin{array}{c}\text { Старші курси, } \mathrm{n} \\
(\%)\end{array}$ & $\begin{array}{c}\text { Молодші курси, } \\
\mathrm{n}(\%)\end{array}$ & $\begin{array}{c}\text { Старші курси, } \mathrm{n} \\
\text { (\%) }\end{array}$ \\
\hline Образний & $6(22)$ & $4(16)$ & $5(18)$ & $3(11)$ \\
\hline Образно-логічний & $3(11)$ & $1(6)$ & $3(11)$ & $2(8)$ \\
\hline Образно-інтуїтивний & $1(3)$ & $5(20)$ & $3(10)$ & $4(20)$ \\
\hline Логічний & $5(16)$ & $4(18)$ & $3(11)$ & $1(5)$ \\
\hline Логічно-інтуїтивний & $2(8)$ & $1(5)$ & $2(9)$ & $1(5)$ \\
\hline Інтуїтивний & $10(35)$ & $5(22)$ & $6(22)$ & $5(18)$ \\
\hline Змішаний & $8(28)$ & $1(5)$ & $8(28)$ & $1(5)$ \\
\hline Усього & 35 & 20 & 108 & 72 \\
\hline
\end{tabular}

Таблиця 2

Результати невисоких ПКС (менше 20 тис. у. од.), схожих для обох пальців із урахуванням типу мислення за тестами

\begin{tabular}{|l|c|c|c|c|}
\hline \multirow{2}{*}{ Тип мислення } & \multicolumn{2}{|c|}{ 3-й палець } & \multicolumn{2}{c|}{ 4-й палець } \\
\cline { 2 - 5 } & $\begin{array}{c}\text { Молодші курси, } \\
\mathrm{n}(\%)\end{array}$ & $\begin{array}{c}\text { Старші курси, } \mathrm{n} \\
(\%)\end{array}$ & $\begin{array}{c}\text { Молодші курси, } \\
\mathrm{n}(\%)\end{array}$ & $\begin{array}{c}\text { Старші курси, } \mathrm{n} \\
(\%)\end{array}$ \\
\hline Образно-логічний & $5(14)$ & $2(8)$ & $5(18)$ & $2(8)$ \\
\hline Образно-інтуїтивний & $2(7)$ & $1(4)$ & $2(7)$ & 0 \\
\hline Логічно-інтуїтивний & $1(3)$ & $4(17)$ & $1(3)$ & $5(21)$ \\
\hline
\end{tabular}

різниць (менше 10 \% від більшої величини) між ПКС після різних тестів (табл. 1).

3 табл. 1 видно, що в цілому частота ПКС 3 максимумом вище 20 тис. у. од. серед молодших студентів була більшою, що відображає високу реактивність і енергетичну відповідь у процесі тестування. В порівнянні з молодшими студентами, у старших не набагато рідше зустрічався образний i інтуїтивний тип мислення, значно частіше - образно-інтуїтивний. Зникав практично змішаний тип, тобто визначалася перевага якогось типу розумового процесу, залежно від конституційних особливостей особистості; в міру накопичення інформації і практичних навиків формувалося синтетичне сприйняття інформації.

У табл. 2 представлені дані типу мислення у студентів за схожими величинам при ПКС менше 20 тис. у. о. після двох різних тестів і більш низькою величиною після третього виду тесту, що відображає низьку реактивність регулюючих систем.
При аналізі подібних, не максимальних величин ПКС виявили, що у студентів молодших курсів частіше було образно-логічне мислення, у старших логічно-інтуїтивне, причому на обох пальцях. При високій реактивності відповіді логічний тип мислення був найбільш рідкісним. Очевидно, різні уявні процеси пов'язані з різною інтенсивністю енергообміну і більш енергетично — 3 проявами інтуїції.

Провели аналіз максимальних величин ПКС на 3-му та 4-му пальцях в зіставленні їх з типами мислення, встановленими за тестами (табл. 3).

У половини студентів молодших курсів образний і логічний тип мислення виявлялися близькими за величиною ПКС на обох пальцях (серцево-судинна та ендокринна системи, психіка), що відображає єдність і взаємозв'язок регулюючих систем в організмі. У більшості старших студентів виявили такі ж закономірності при всіх типах мислення.

У меншої частини студентів активація біоенергії на тестові завдання виявлялася по-різному. Зокрема, у молодших студентів при логічному 
Порівняння ПКС на пальцях при різних типах мислення

\begin{tabular}{|c|c|c|c|c|c|c|}
\hline \multirow{2}{*}{ Тип мислення } & \multicolumn{3}{|c|}{ Молодші курси, \% } & \multicolumn{3}{c|}{ Старші курси, \% } \\
\cline { 2 - 7 } & $1^{*}$ & $2 *$ & $3^{*}$ & 1 & 2 & 3 \\
\hline Образний & 56 & 38 & 16 & 67 & 24 & 6 \\
\hline Логічний & 53 & 11 & 34 & 68 & 24 & 18 \\
\hline Інтуїтивний & 41 & 43 & 24 & 58 & 18 & 23 \\
\hline
\end{tabular}

*Примітки: 1 - значення на 3-му та 4-му пальцях близькі між собою; 2 - значення ПКС більше на 3-му пальці; 3 - значення ПКС більше на 4-му пальці

типі мислення ПКС була більше на 4-му пальці, тобто пов'язана з активністю гіпофізарно-гіпоталамічної сфери регуляції рефлекторного характеру. У старших студентів ПКС частіше була більше на 3-му пальці, що відображає первинну активацію серцево-судинного сприйняття інформації. При інтуїтивному типі мислення у студентів молодших курсів максимальна ПКС найчастіше зустрічалася на 3-му пальці, тобто зв'язана перш за все 3 судинними реакціями, у старших студентів - на 4-му пальці, що віддзеркалює віковий розвиток ендокринних систем.

Такі ж закономірності простежуються й на кольоровій фотоплівці. Використання гістограм яскравості пікселів для трьох базових кольорів (червоного, зеленого, синього), кожну з яких нормують відносно її глобального екстремуму, дозволяє за допомогою програмного забезпечення автоматизувати аналіз характерних ознак кожної гістограми та встановити їх відповідність типам енергетичної активації людини.

На рис. 1 (а, б, в) представлено різні типи ГРС руки на кольоровій фотоплівці «Поляроїд». Позначили MaxR амплітуду глобального екстремуму для гістограми червоного кольору. Аналогічно через MaxG і MaxВ позначили відповідно максимальні амплітуди для гістограм зеленого і синього компонента. Для побудови вирішальних логічних правил класифікації скористалися наступними кількісними показниками, фізичний зміст яких полягає в оцінці рівномірності вкладів RGBкомпонент в інтегральному спектрі випромінювання, які аналітично обчислювали як безрозмірні коефіцієнти відносини максимальних амплітуд гістограм:

$$
K_{G R}=\frac{\operatorname{Max}_{G}}{\operatorname{Max}_{R}} \quad K_{B R}=\frac{\operatorname{Max}_{B}}{\operatorname{Max}_{R}} .
$$




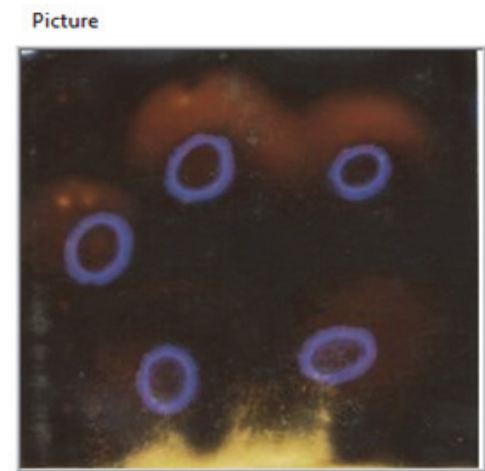

max value RED max value GREEN max value BLUE 2661

max index RED

max index GREEN max index BLUE

39

$$
32
$$

22
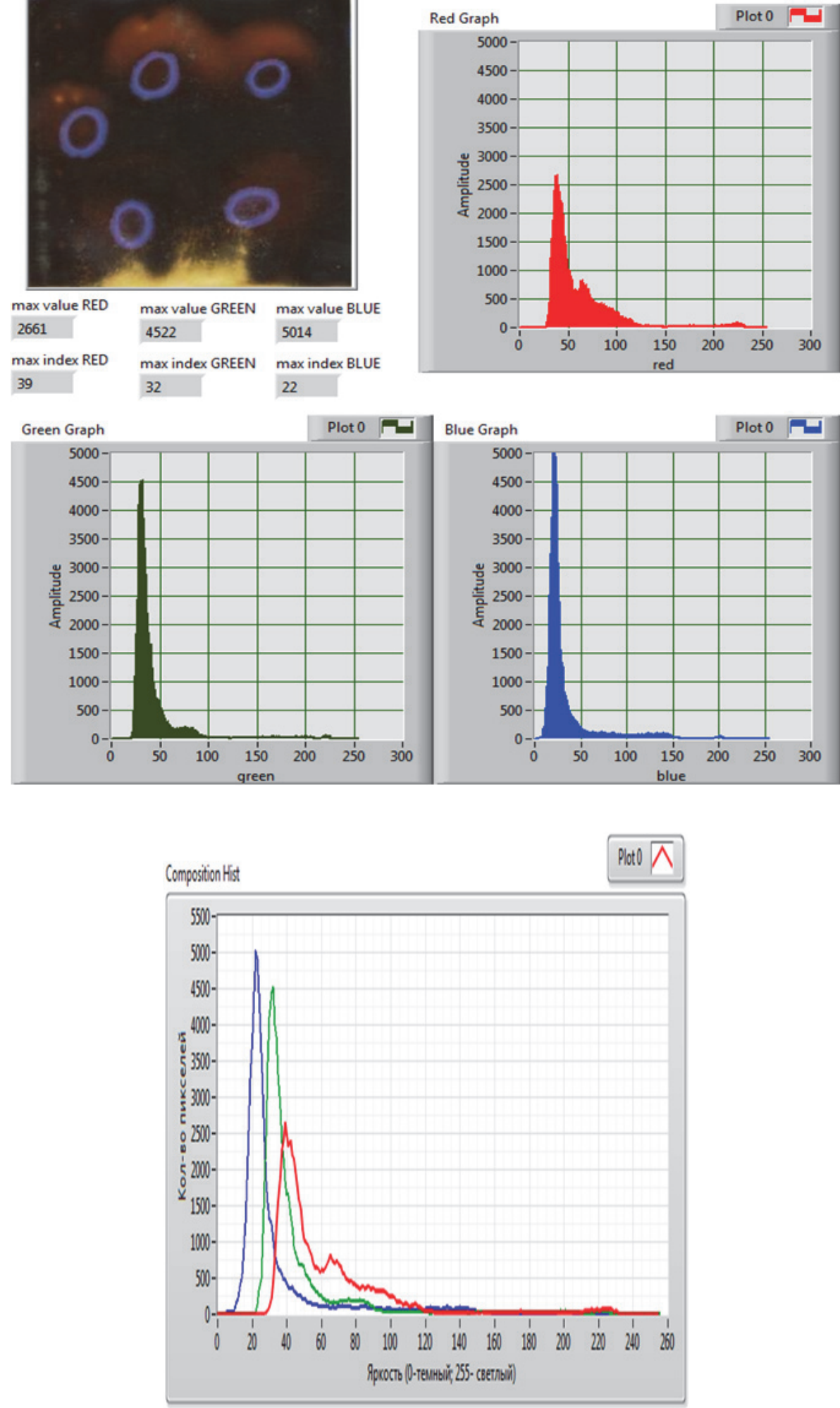

$$
K_{G R}=1,70 ; K_{B R}=1,88
$$

a) 

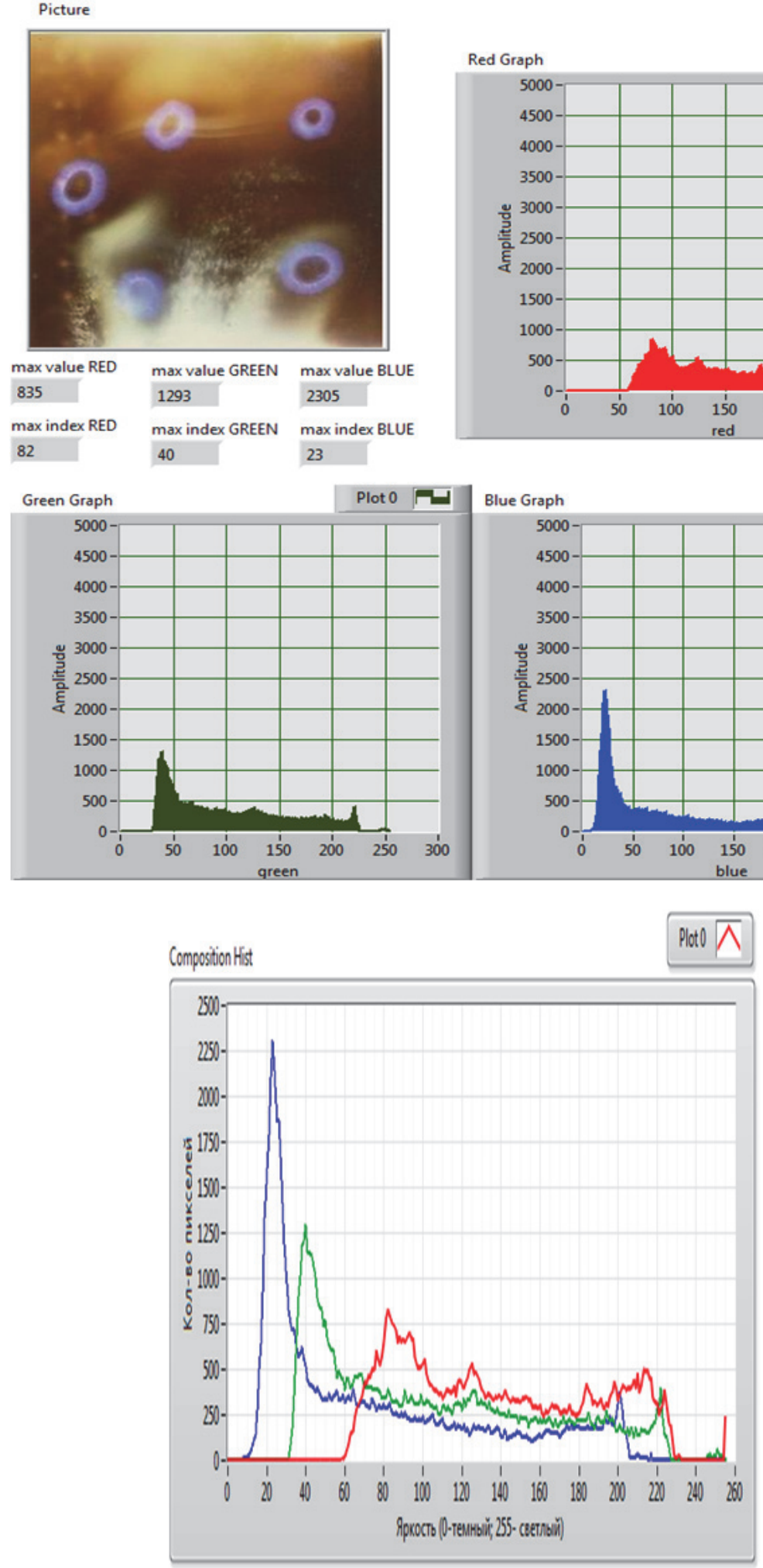

$$
K_{G R}=1,54 ; K_{B R}=2,76
$$



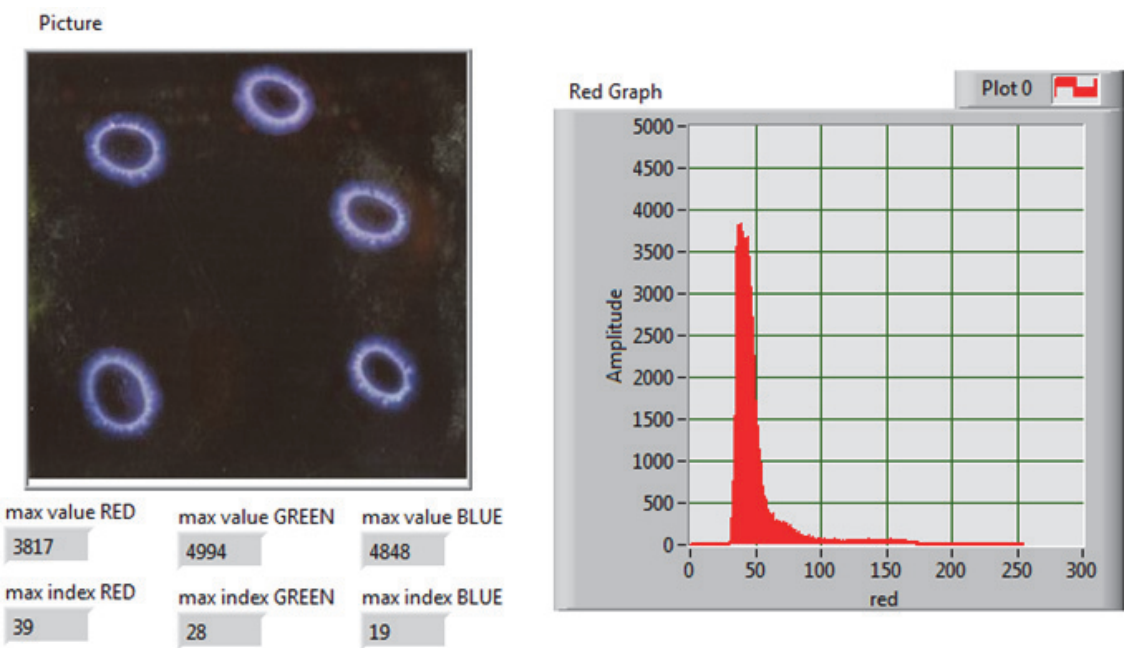

28

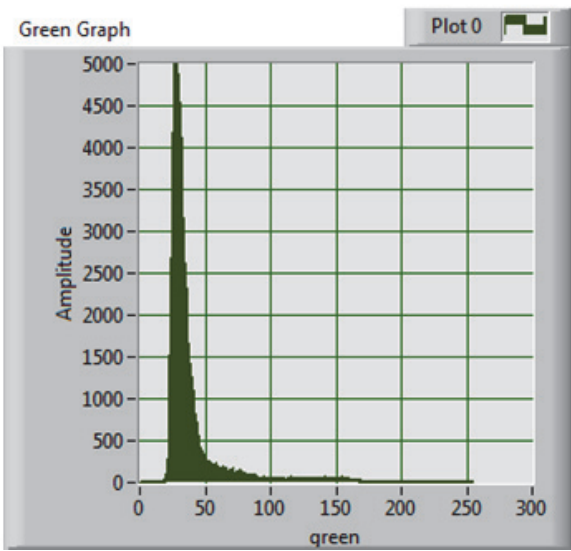

Blue Graph

Plot 0
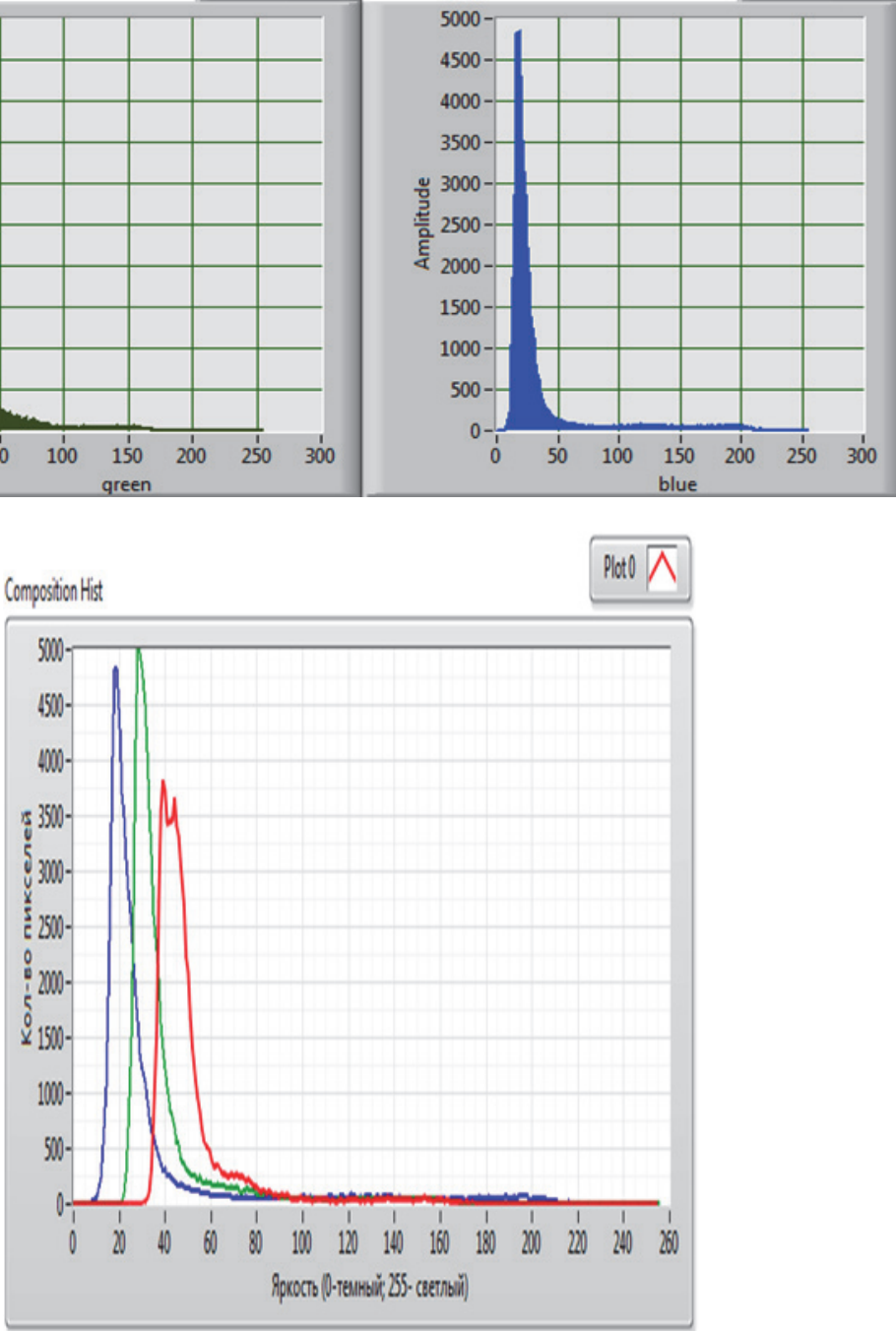

$K_{G R}=1,31 ; K_{B R}=1,27$

B)

Рис. 1. Приклади ГРС руки у студентів із різним психоемоційним станом на фотоплівці «Поляроїд» (а, б, в) 

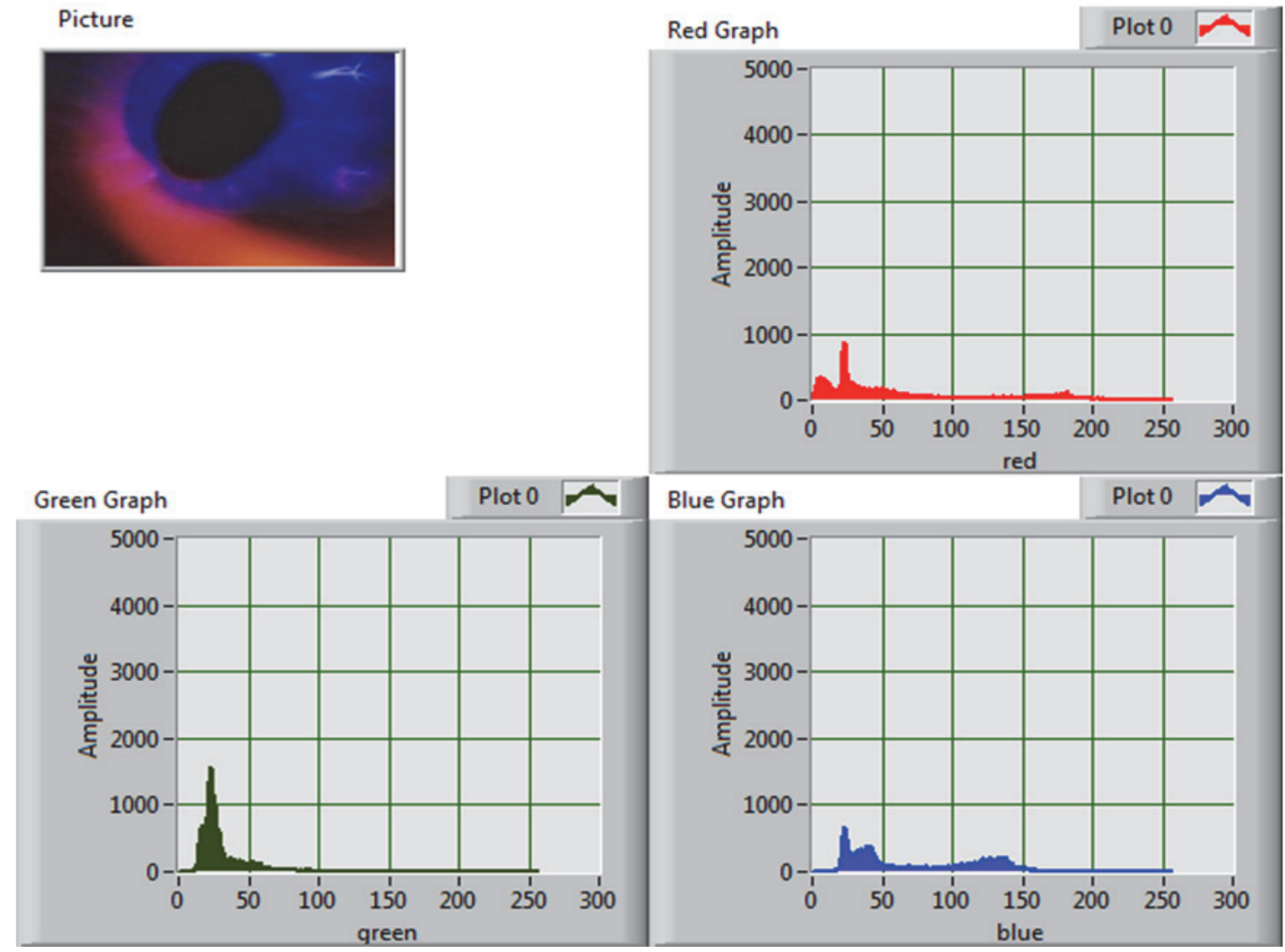

Рис. 2. Кірліанограма пальця руки на кольоровій фотоплівці «Кодак 200»

На рис. 2 та 3 наведено приклади кірліанограм окремих пальців руки на кольоровій фотоплівці «Кодак 200».

Використання як характерних ознак кожної гістограми значення яскравості глобального максимуму Di, відносної кількості пікселів першого після нього локального екстремуму $\mathrm{Ni}$ дозволяє здійснювати їх класифікацію відносно двох класів, які визначають в процесі преднавчання як відповідні ментально-емоційний та рефлекторно-екстрасенсорний типи енергетичної активації організму людини. Характерні ознаки для першого класу, що відповідає стану ментально-емоційної активності, мають, щонайменш для двох кольорів, такі значення: $\mathrm{Di}<30,0$; $0,1<\mathrm{Ni}<0,8$. Інформативні ознаки для другого класу, що відповідає стану рефлекторно-екстрасенсорної активності, мають, щонайменш для гістограм двох кольорів, такі значення: $\mathrm{D}>30$ при $\mathrm{Ni}>0,8$ або $\mathrm{Ni}<0,1$.

Використання кольорових зображень газорозрядного світіння характеризується більшою інформативністю порівняно 3 півтоновими. Енергія переходу електрону залежить як від величини зовнішнього електричного поля, так і від електронного стану досліджуваного об’єкту. Тому у різних областях оточуючого об’єкт електричного поля електрони отримують різні імпульси енергії, тобто «перестрибують» на різні енергетичні рівні. Це приводить до випромінювання квантів світла різної довжини хвилі (частоти) та енергії, що забарвлюють зону газорозрядного світіння у різні кольорові гамми.

При червоному кольорі ця енергія становить 1,82 еВ (1 еВ = 1,602 176 6208(98)·10-19 Дж), при жовтогарячому кольорі - 2,05 еВ; при жовтому 2,14 еВ; при синє-зеленому - 2,43 еВ, при синьому — 2,64 еВ; при фіолетовому — 3,03 еВ. Отже, чим більше переважають у спектрі жовті, жовтогарячі, сині, синє-зелені та фіолетові кольори, тим яскравіше виражена газорозрядна візуалізація та біоелектричні властивості об’єкту.

Звертає на себе увагу наявність додаткових світінь, крім корони пальців, в стані активності психоемоційних реакцій. Чим вище активність, тим більше відрізняються коефіцієнти К і різноманітність кривих на графіку, що відображає різноманіття спектра світіння. 

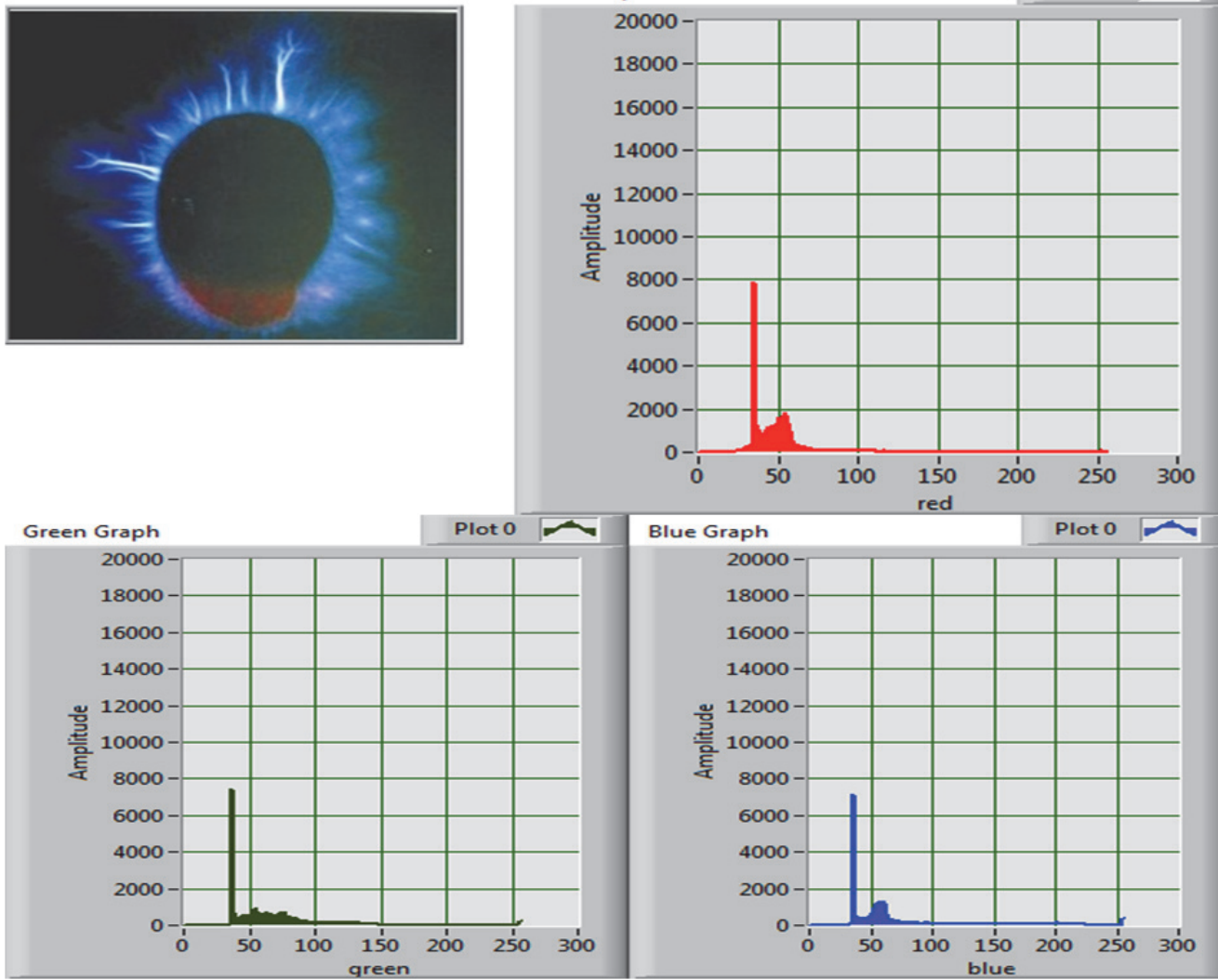

Picture

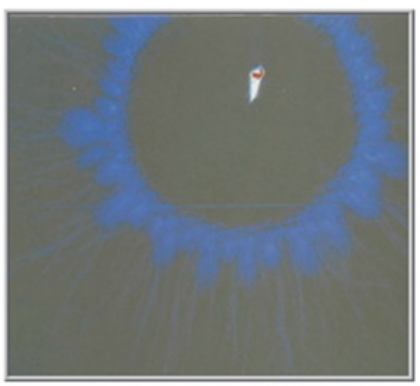

max value RED

4102

max index RED

103

Green Graph

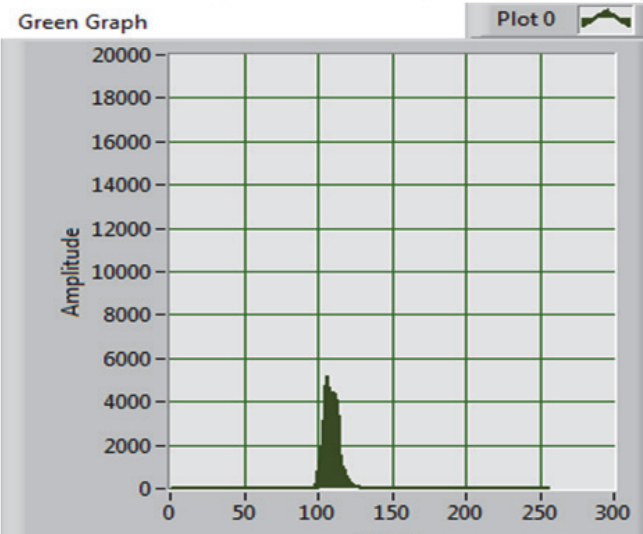

Red Graph

Plot 0

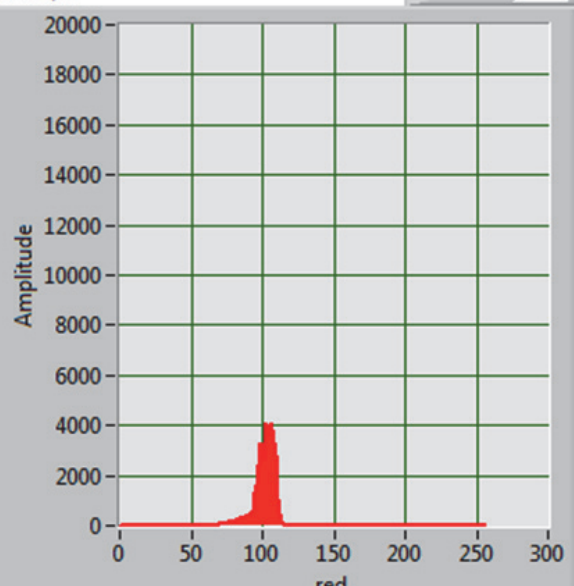

Blue Graph Plot $0 \curvearrowright$

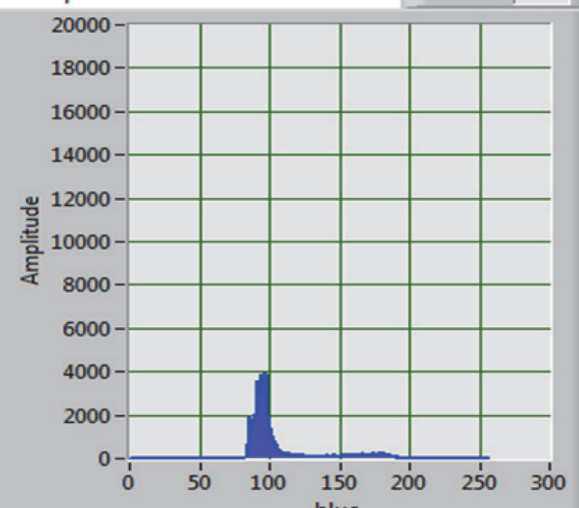

Рис. 3 Кірліанограма пальців руки на кольоровій фотоплівці «Кодак 200» в стані спокою та при психоемоційній активності 


\section{Висновки.}

1. Результати ГРС корони навколо пальців рук студентів дозволили доповнити результати психологічних тестів на тип мислення, що треба враховувати для індивідуалізації навчального процесу.

2. Реєстрація на кольоровій фотоплівці кірліанівського випромінювання навколо пальців рук дозволяє визначити тип психоемоційної активації організму, потенційні власні здібності студента, що може оптимізувати навчання в університеті.

\section{Література.}

1. Народная и нетрадиционная медицина Украины. К., 2003. - Вып. 1. - С. 26.

2. Оценка энерго-информационного гомеостаза организма человека при помощи метода газоразрядной визуализации / Л. А. Песоцкая, Н. В. Глухова, Н. Г. Кучук, Н. М. Евдокименко // Системи обробки інформації. - 2016. - Вип. 8 (145). - С. 133-138.

3. Пат. 49283 UA, МПК А61B5/05. Способ экспрессдиагностики психоэмоционального состояния человека / Песоцкая Л. А., Новицкий А. Ю., Райнберг В. А. та ін. — опубл. 16.09.2002 ; Бюл. № 9.

4. Kraweck A. Life's hidden forses - a personal journey into Kirlian protograph / A. Kraweck. - Canada : Triune-being research organization Ltd, 1998. — 100 p.

5. Mandel P. Energetishe terminalpunkt diagnose / P. Mandel. — Essen : Synthesis Verlag, 1983. — 199 p.

6. Milhones N. Official Brazilian standard of Kirlian cameras and kirliangraphy / N. Milhones. - Brazil, 1986.

\section{References.}

1. Narodnaja i netradicionnaja medicina Ukrainy [Folk and non-traditional medicine of Ukraine]. (2003). Iss. 1. Kiev.

2. Pesockaja, L. A., Gluhova, N. V., Kuchuk, N. G., \& Evdokimenko, N. M. (2016). Ocenka jenergoinformacionnogo gomeostaza organizma cheloveka pri pomoshhi metoda gazorazrjadnoj vizualizacii [Assessment of the energy-information homeostasis of the human body using the gas-discharge imaging technique]. Sistemi obrobki informacii (Information processing systems), 8 (145), 133-138.

3. Pesockaja, L. A., Novickij, A. Ju., Rajnberg, V. A., Koreckij, A. Ju., \& Ilaev, T. M. Sposob jekspressdiagnostiki psihojemocional'nogo sostojanija cheloveka [The method of express diagnostics of a person's psychoemotional state]. Patent 49283 UA, MPK A61V5/05. Bul. No. 9.

4. Kraweck, A. (1998). Life's hidden forses - a personal journey into Kirlian protograph. Canada: Triune-being research organization Ltd.

5. Mandel, P. (1983). Energetishe terminalpunkt diagnose. Essen: Synthesis Verlag.

6. Milhones, N. (1986). Official Brazilian standard of Kirlian cameras and kirliangraphy. Brasil. 